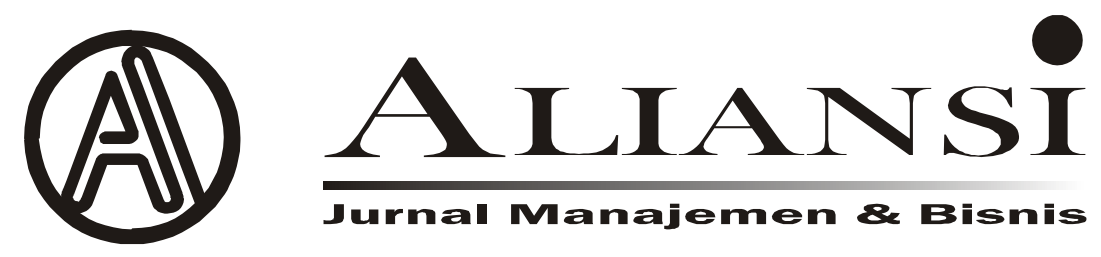

\title{
MOTIVASI MASYARAKAT DALAM MEMILIH PEMIMPIN Studi Kasus Pada Pemilihan Kepala Desa Hargomulyo, Gedangsari, Gunungkidul
}

\author{
Oleh : Indri Astuti ${ }^{1}$ dan Widodo ${ }^{2 *}$
}

\begin{abstract}
Society always hunger for a leader which can be expected by its protecting people is more when commutation moment hence people surely hope the leader which will more baih in holding governance wheel.

At writer opportunity start from survey later; then communicate with the society of either through direct and also through/passing media social later; then do/conduct this research with the descriptive method qualitative

Hence at this opportunity is writer will pare and explain how society motivation in chosening leader?

Highest expectation $31 \%$ improving people earnings, equal to $15 \%$ that is hold responsible. equal to $13 \%$, People $11 \%, 11 \%$, in activity $R T / r w 8 \%$, Cleanness $5 \%, 3 \%$, and Agamis $3 \%$.

Suggestion from writer that society of if wishing happy peaceful and prosperous life and also have to and is obliged to remember the Allah swt. by diligent of religious service. Because place Allah curtsey and place ask. If that leader as medium or medium, because good leader is which religious

Keyword: Motivate and Leader

\section{PENDAHULUAN}

Pada dasarnya pemimpin akhir-akhir ini terus dipacu untuk mencapai Manajemen Peningkatan Mutu dalam Organisasi atau instansi (MPM), yaitu suatu model manajemen pekerjaan yang memberikan otonomi lebih luas kepada organisasi atau instansi untuk mengambil keputusan secara partisipasif dengan melibatkan segenap warga organisasi atau instansi

Karena peranan pemimpin dalam organisasi sangat penting maka menjadi kewajiban utama bagi setiap pemimpin untuk selalu terus menerus berusaha, mengamati dan memahami tingkah laku bawahan, mencari dan menentukan terjadinya tingkah laku bawahan, memperhitungkan, mengawasi dan mengubah serta mengarahkan tingkah laku bawahan agar dapat menjalankan tugas sesuai dengan fungsinya, terutama yang berkaitan dengan pemerintahan pedesaan menjadi tanggung jawab Kepala Desa (Lurah). Sehingga tujuan organisasi dapat dicapai sesuai dengan rencana.

Apabila setiap kehidupan suatu organisasi diadakan pengamatan secara cermat akan nampak lebih jelas peranan menajemen administrasi (administrative management) melalui tindakantindakan perencanaan pengorganisasian, pengarahan,

koordinasi, kontrol dan evaluasi serta komunikasi yang dikembangkan oleh Kepala Desa sebagai administrator, untuk mewujudkan kerja yang efektif dan terarah dengan suatu tujuan tertentu.

Didalam kehidupan suatu organisasi pemerintahan apabila dicermati serta diamati akan terjadi proses interaksi kerja sama antara pemimpin dengan bawahan yang diperhatikan, diarahkan, dibina, dan dikembangkan, tetapi kemungkinan juga dipaksakan, agar perilaku tersebut sesuai dengan harapan pemimpin di dalam suatu lembaga.

Pada era kontemporer, organisasi dilandasi ketergantungan (Depedency) dan keperkiraan (Proximity) sebagai akibat kemajuan teknologi dan perkembangan penduduk, sehingga pengertian organisasi berkembang mengikuti interaksi antara sistem formal dengan komponen-komponen manusia. Maka organisasi pemerintahan merupakan wadah yang berfungsi menyelenggarakan proses pelayanan masyarakat.

Dalam rangka melaksanakan, megelola, mengurus dan mengatur diperlukan manajemen yaitu proses memimpin, membimbing, menyiapkan fasilitas kepada bawahan supaya bekerja sama untuk mencapai tujuan bersama.
\end{abstract}

\footnotetext{
* Dosen STIMA IMMI dan STIE IPWIJA
} 
Motif dari masyarakat adalah suatu harapan yang dinginkan baik harapan masa depan dari dirinya sendiri maupun harapan masa depan yang ditmbulkan akibat perbuatan orang lain.

Sering terjadi pimpinan organisasi beralasan dari organisasi atau lembaga lain yang tidak dikenal sebelumnya oleh para pegawai atau bawahan yang memiliki basic, kompetensi, serta kualitas kepemimpinan maupun sikap individunya.

Berdasarkan latar belakang masalah di atas, Penulis menganggap penting perlunya dikaji masalah Motivasi masyarakat dalam memilih pemimpin di Desa Hargomulyo, Gedangsari, Gunungkidul, untuk mengamati permasalahan yang timbul serta mencari solusi yang terbaik.

Kepala Desa selaku pemimpin yang memegang kendali organisasi, sangat penting dan strategis dalam kontek pembangunan ekonomi dan tidak kalah pentingnya sebagai motivator, dan suritauladan. Bila kedua hal tersebut tidak berjalan dengan baik maka akan terjadi kemerosotan dan menurunnya misi yang diemban tidak sesuai dengan apa yang diharapkan oleh masyarakat.

Maka penulis ingin dan berminat untuk mengadakan penelitian yang berhubungan dengan halhal yang berkaitan di atas, guna kepentingan penelitian tersebut penulis mengetengahkan judul penelitian "Motivasi masyarakat dalam memilih pemimpin di Desa Hargomulyo, Gedangsari, Gunungkidul.”

\section{TINJAUAN TEORI (LITERATURE REVIEU) Motivasi masyarakat}

Motif adalah suatu harapan yang dinginkan baik harapan masa depan dari dirinya sendiri maupun harapan masa depan yang ditmbulkan akibat perbuatan orang lain.

Menurut Cut Zurnali (2004), motif adalah faktorfaktor yang menyebabkan individu bertingkah laku atau bersikap tertentu. Jadi dicoba untuk menjawab pertanyaan-pertanyaan seperti kebutuhan apa yang dicoba dipuaskan oleh seseorang? Apa yang menyebabkan mereka melakukan sesuatu pekerjaan atau aktivitas. Ini berarti bahwa setiap individu mempunyai kebutuhan yang ada di dalam dirinya (inner needs) yang menyebabkan mereka didorong, ditekan atau dimotivasi untuk memenuhinya. Kebutuhan tertentu yang mereka rasakan akan menentukan tindakan yang mereka lakukan.

Mengacu pada pendapat Victor Vroom, Cut Zurnali (2004)mengemukakan bahwa ekspektasi adalah adanya kekuatan dari kecenderungan untuk bekerja secara benar tergantung pada kekuatan dari pengharapan bahwa kerja akan diikuti dengan pemberian jaminan, fasilitas dan lingkungan atau outcome yang menarik.

Dengan merumuskan beberapa pendapat para ahli, Cut Zurnali (2004) menyatakan bahwa terdapat dua sumber besar yang dapat mempengaruhi kelakuan individu, yaitu: sumber-sumber harapan yang berkenaan dengan peranannya antara lain, tuntutan formal dari pihak pekerjaan yang terperinci dalam tugas yang seharusnya dilakukan. Dan tuntutan informal yang dituntut oleh kelompok-kelompok yang ditemui individu dalam lingkungan kerja

Dari definisi di atas maka motivasi adalah suatu proses kegiatan seseorang dalam hal memimpin, membimbing, mempengaruhi atau mengontrol pikiran, perasaan dari tingkah laku terhadap orang lain yang ada di bawah pengawasannya. Sehingga motivasi yang efektif adalah motivasi yang dapat atau mampu menumbuhkan, memelihara dan mengembangkan usaha dan iklim yang kooperatif dalam kehidupan organisasi dan pada akhirnya dapat meningkatkan kinerja.

\section{Pemimpin}

Pemimpin akhir-akhir ini terus dipacu, sejalan dengan penerapan memimpin organisasi atau instansi dalam konteks Manajemen Peningkatan Mutu dalam Organisasi atau instansi (MPM), yaitu suatu model manajemen pekerjaan yang memberikan otonomi lebih luas kepada organisasi atau instansi untuk mengambil keputusan secara partisipasif dengan melibatkan segenap warga organisasi atau instansi.

Seperti dikemukakan oleh Direktur Pekerjaan Umum, (2002: h.4), yang mengatakan bahwa :

"Pemimpin instansi memiliki kekuasaan yang lebih besar untuk mengambil keputusan berkaitan dengan kebijakan pengelolaan organisasi atau instansi dibandingkan dengan sistem manajemen pekerjaan yang dikontrol pusat. Seberapa besar kekuasaan organisasi atau instansi tergantung seberapa jauh Manajemen berbasis organisasi atau instansi (MBO) dapat diimplikasikan. Pemberian kekuasaan secara utuh sebagaimana dalam teori MBS tidak mungkin dilaksanakan seketika, ada proses transisi dari manajemen dikontrol oleh pusat ke MBO, kekuasaan yang lebih besar yang dimiliki oleh Pimpinan Organisasi atau instansi dalam pengambilan keputusan perlu dilaksanakan dengan demokratis".

Martinis Yamin dan Maisah (2010: 74) kepemimpinan adalah suatu proses mempengaruhi yang dilakukan oleh seseorang dalam mengelola anggota kelompoknya untuk mencapai tujuan 
organisasi. Kepemimpinan merupakan bentuk strategi atau teori memimpin yang tentunya dilakukan oleh orang yang biasa kita sebut sebagai pemimpin. Pemimpin adalah seseorang dengan wewenang kepemimpinannya mengarahkan bawahannya untuk mengerjakan sebagian dari pekerjaannya dalam mencapai tujuan.

Menurut pendapat Wahjosumidjo (2005) kepemimpinan diterjemahkan ke dalam istilah sifatsifat, perilaku pribadi, pengaruh terhadap orang lain, pola- pola, interaksi, hubungan kerja sama antarperan, kedudukan dari satu jabatan administratif, dan persuasif, dan persepsi dari lain- lain tentang legitimasi pengaruh.

Dari sejumlah pengertian kepemimpinan menurut para ahli di atas dapat disimpulkan kepemimpinan merupakan cara seorang pemimpin dalam mempengaruhi bawahan dengan karakteristik tententu sehingga dapat mencapai tujuan yang diinginkan. Faktor keberhasilan seorang pemimpin diantaranya tergantung pada teknik kepemimpinan dalam menciptakan situasi sehingga menyebabkan orang yang dipimpinnya timbul kesadarannya untuk melaksanakan apa yang dikehendaki dan mapu dalam pembagian kerja, harus kerja sama secara ikhlas, ada motivasi pada pekerja baik material maupun moral ada pemimpin dan sebagainya. Pemimpin harus melakukan fungsi controlling (pengendalian), karena:

a. Supaya tidak terjadi penyimpangan dalam melaksanakan rencana yang telah ditetapkan.

b. Harus mengukur apakah hasil yang dicapai sesuai dengan rencana.

c. Harus mengadakan perbaikan jika terjadi penyimpangan.

Atas dasar teori Motivasi dan pemimpin tersebut maka rakyat Hargomulyo telah menetukan indicator untuk memilih calon pemimpin (Kepala Desa) yang mereka tharpkan akan menjadi pemimpin ideal bagi mereka. Indicator tersebut adalah:

1) Aktif dalam kegiatan RT/RW.

2) Komunikatif

3) Merakyat.

4) Meningkatkan pendapatan rakyat.

5) Penampilan

6) Terkenal

7) Agamis

8) Bersih

9) Mampu

10) Jujur

11) Bertanggung jawab

12) Berjiwa besar

\section{METODE PENELITIAN}

\section{Tempat Penelitian dan waktu}

Penelitian ini dilaksanakan di Kelurahan Hargomulyo, Kecamatan Gedangsari, Kabupaten Gunungkidul, Provinsi Daerah Istimewa Yogyakarta, pada tahun 2019.

\section{Jenis penelitian}

Penelitian yang dilakukan oleh Penulis untuk mengetahui apa sebenarnya motivasi atau harapan masayarakat ketika mereka menentukan pilihan dalam pemilihan kepala desa, oleh karena itu jenis penelitan yang digunakan adalah penelitian survey dan wawancara.

Dengan menggunakan jenis penelitian ini diharapkan mampu menggali informasi tentang motivasi masyarakat, serta akan diperoleh gambaran tingginya rendahnya motivasi atau motif atau harapan masyarakat terhadap pemilihan kepala desa.

Karena itu penelitian ini bersifat deskriptif kualitatif, karena bukan berdasarkan angka secara mutlak akan tetapi menggali apa sebenarnya motif atau harapan masayakat terhadap calon pemimpin mereka dalam hal ini adalah kepala desa yang akan dipilih.

\section{HASIL DAN PEMBAHASAN/DISKUSI}

Hargomulyo, Sabtu 19 Oktober 2019 Panitia Pilkades Desa Hargomulyo Kecamatan Gedangsari Kab. Gunungkidul melaksanakan tahapan Soaialisasi dan Deklarasi Pilkades Damai. Acara tersebut dilaksanakan di aula balai desa Hargomulyo mulai pukul 9.00 WIB dan dihadiri oleh Camat Gedangsari, Forkompinca kec. Gedangsari, Pemerintah Desa dan Tokoh masyarakat. Penandatanganan Deklarasi Pilkades Damai oleh Calon Kepala Desa disaksikan langsung oleh Camat Gedangsari, Kapolsek Gedangsari, Danramil Gedangasari dan Plt. Kepala Desa.

Pemerintah Desa berharap agar seluruh masyarakat Hargomulyo untuk saling menjaga kerukunan dan mendukung pilkades damai agar tercipta pilkades yang aman, damai dan sejuk.

Hari Rabu, tanggal 16 Oktober 2019 Panitia Pemilihan Kepala Desa Hargomulyo telah melaksanakan Tahapan Penetapan Daftar Pemilih Tetap pemilihan Kepala Desa masa jabatan 20202025. Berdasarkan hasil pemutakhiran Daftar pemilih yang telah dilaksanakan oleh Petugas Pemutakhiran Data Pemilih (PPDP) dan berdasarkan evaluasi pemutakhiran data pemilih bersama Dukuh se-Desa 
Hargomulyo di peroleh daftar pemilih yang telah ditetapkan panitia pemilihan Pilkades adalah sebagai berikut:

\section{Gambar : 1}

REKAPITULASI DAFTAR TETAP PEMILIHAN KEPALA DESA HARGOMULYO

$\begin{array}{ll}\text { KABUPATEN } & \text { :GUNUNGKIDUL } \\ \text { KECAMATAN } & : \text { GDANGSARI }\end{array}$ TAHUN 2019

$\begin{array}{ll}\text { KECAMATAN } & : \text { GDANGSARI } \\ \text { DESA } & : \text { HARGOMULYO }\end{array}$

\begin{tabular}{|c|c|c|c|c|c|c|}
\hline \multirow{2}{*}{ NO. } & \multirow{2}{*}{\multicolumn{2}{|c|}{ TPS }} & \multicolumn{3}{|c|}{ DPT } & \multirow[b]{2}{*}{ KET. } \\
\hline & & & PRIA & WANITA & JML & \\
\hline 1. & 1 & GEDANGAN & 241 & 234 & 475 & \\
\hline 2. & 2 & PACE A & 122 & 121 & 243 & \\
\hline 3. & 3 & PACE B & \begin{tabular}{|l|}
226 \\
\end{tabular} & 213 & 439 & \\
\hline 4. & 4 & NGASINAN & 149 & 145 & 294 & \\
\hline 5. & 5 & JETIS & 268 & 275 & 543 & \\
\hline 6. & 6 & BULU & 259 & 257 & 516 & \\
\hline 7. & 7 & BALONG & 206 & 197 & 403 & \\
\hline 8. & 8 & JATIREJO & 216 & 226 & 442 & \\
\hline 9. & 9 & JAMBON & 154 & 160 & 314 & \\
\hline 10. & 10 & MANGLI & 191 & 192 & 383 & \\
\hline 11. & 11 & JATIBUNGKUS & 255 & 239 & 494 & \\
\hline 12. & 12 & SURUH & 300 & 336 & 636 & \\
\hline 13. & 13 & SURU LOR & \begin{tabular}{|l|}
119 \\
\end{tabular} & 125 & 244 & \\
\hline 14. & 14 & SURU KIDUL & 111 & 116 & 227 & \\
\hline \multicolumn{3}{|c|}{ JUMLAH } & 2817 & 2836 & 5653 & \\
\hline
\end{tabular}

Sumber : Hasil penelitian 2019

Pada acara ini dihadiri oleh Sekretaris Camat Gedangsari, Danramil Kecamatan Gedangsari, Babhinkamtibmas Desa Hargomuly, Ketua BPD , Plt Kepala Desa beserta perangkat dan 2 calon Kepala Desa yang telah ditetapkan pada tanggal 14 Oktober 2019.

Selanjutnya Daftar pemilih tetap ini dituangkan pada peraturan Panitia Pemilihan kepala desa nomor 8/KPTS/2019 tahun 2019 tentang Penetapan Daftar Pemilih Tetap Pemilihan Kepala Desa Masa Jabatan 2020-2025

Tahapan Pelaksanaan Pemilihan Kepala Desa Hargomulyo hari Senin 14 Oktober 2019 telah memasuki Tahapan Pengundian Nomor dan penetapan Calon Kepala Desa. Dari dua bakal calon yang mendaftar sebagai calon kepala desa semuanya memenuhi syarat untuk mengikuti tahapan pengundian nomor dan penetapa calon kepala desa. Tahapan yang dilaksanakan di Aula Pendopo Balai Desa Hargomulyo ini dihadiri langsung oleh Kepala Dinas DP3AKBPM\&D Kabupaten Gunungkidul Bapak Sujoko, S.Sos, M.Si, Camat Gedangsari yang diwakili oleh Kepala Seksi Tata Pemerintahan, Kapolsek Gedangsari, Danramil Gedangsari dan BPD Desa Hargomulyo.

Dalam sambutannya Kepala Dinas DP3AKBPM\&D Kabupaten Gunungkidul mengapresiasi atas kinerja Panitia Pemilihan Kepala
Desa Hargomulyo yang telah bekerja dengan baik sehingga semua proses dan tahapan pemilihan kepala desa di Desa Hargomulyo dapat berjalan dengan baik dan telah sesuai dengan tahapan yang telah ditetapkan oleb Bupati Gunungkidul. Selain itu beliau juga mengapresiasi pelaksanaan pengundian Nomor dan penetapan Calon Kepala Desa di Desa Hargomulyo dapat berjalan dengan aman dan tertib sehingga tidak terjadi gesekan antar pendukung calon.

Selanjutnya sebelum proses pengundian nomor dilaksanakan Bapak Arif Munasir selaku Ketua Panitia Pemilihan Kepala Desa membacakan Keputusan Panitia Pemilihan Kepala Desa tentang Penetapan bakal calon kepala desa sebagai dasar Pengundian Nomor Dan Penetapan Calon Kepala Desa Hargomulyo. Inti dari keputusan tersebut adalah dari 2 pendaftar yang telah memasukan berkas lamaran sebagai calon kepala desa dapat diterima dan dapat mengikuti proses pengundian nomor dan Penetapan Calon Kepala Desa.

Dari hasil pelaksanaan Pengundian Nomor maka diperoleh hasil nomor dari masing-masing calon adalah sebagai berikut ini:

1) Ibu MARSINEM, S.Sos, M.Si mendapatkan nomor Urut [ 1 ]

2) Bapak SUMARYANTA mendapatkan nomor urut [ 2 ]

Berdasarkan hasil undian nomor yang telah diperoleh selanjutnya di tuangkan pada Keputusan Panitia Pemilihan kepala Desa Hargaomulyo Nomor 7/KPTS/2019 tentan Calon Kepala Desa yang di tandatangani oleh ketua Panitia Pemilihan kepala Desa Bapak Arif Munasir.

Hari ini Sabtu, 21 September 2019 Panitia Pemilihan Kepala Desa, Desa Hargomulyo Kecamatan Gedangsari Kabupaten Gunungkidul melaksanakan sosialisasi tata tertib pemilihan kepala desa. adapun tata tertib Pilkades terlampir.

Pelatihan Petugas Pemutakhiran Data Pemilih (PPDP) PILKADES Desa Hargomulyo tahun 2019 (Selasa,17/9/19). Pelatihan dilaksanakan oleh Panitia Pemilihan Kepala Desa, Desa Hargomulyo Kecamatan Gedangsari Kabupaten Gunungkidul yang dihadiri Kepala Desa dan FORKOMPINCA Kecamatan Gedangsari beejalan dengan lancar dan sesuai dengan tahapan Pilkades serentak. Adanya pelatihan ini Pemerintah Desa berharap pemutakhiran data pemilih dapat berjalan dengan lancar sesuai peraturan yang berlaku, sehingga dapat ditetapkan Daftar Pemilih Sementara(DPS) sesui dengan tahapan Pilkades serentak di Kabupaten Gunungkidul. 
Suasana memanas terjadi menjelang Pilkades di Desa Hargomulyo, Kecamatan Gedangsari. Dua orang kandidat saling berseteru terkait dengan program unggulannya. Awal mula dari polemik ini dimulai saat salah seorang kandidat, Marsinem dalam kampanyenya menyatakan akan menggratiskan event rasulan bilamana ia menjabat. Program ini lantas diserang calon kades lainnya yang berstatus petahana, Sumaaryanta yang menilai program tersebut tak relevan dengan kondisi Desa Hargomulyo.

Kepada pidjar.com, Marsinem bersikukuh bahwa program tersebut akan ia terapkan jika nantinya terpilih menjadi Kades Hargomulyo. Menurutnya, event semacam ini sebenarnya bisa dicarikan pendanaan tanpa harus membebani masyarakat. Cukup banyak warga perantauan yang sukses maupun sponsor-sponsor yang bisa digandeng untuk membiayai rasulan di desanya. Bahkan selain gratis, ia juga menjamin nantinya rasulan tetap akan berjalan meriah.

"Sesuai dengan pernyataan saya kepada masyarakat, untuk rasulan gratis ini, dalangnya minimal adalah Ki Seno," tandas Marsinem, Kamis (31/10/2019) siang.

Salah satu latar belakang dari keinginannya tersebut adalah, pihaknya merasa perlu untuk mengurangi beban masyarakat. Selama ini setiap rasulan, masyarakat dipungut biaya Rp 30.000 per KK. Jumlah ini mungkin bukan suatu masalah untuk masyarakat dengan ekonomi menengah ke atas. Namun tentu ini akan menjadi beban bagi masyarakat dengan ekonomi lemah.

"Bahkan saya punya angan-angan, ke depan acara yang harus ada lantaran memang sudah menjadi tradisi ini bisa tanpa membebani anggaran pemerintah desa," papar dia.

Berkaitan dengan serangan yang ia terima terkait program ini, Marsinem mengaku tak habis pikir. Tudingan bahwa dengan tidak memungut uang dari masyarakat akan melunturkan gotong royong disebutnya tidak masuk akal. Marsinem menyatakan, gotong royong tidak sebaiknya dinilai dengan uang. Gotong royong adalah niat dari masyarakat untuk bergerak bersama dan saling membantu.

"Justru ini yang akan saya kembangkan jika saya mendapatkan amanah. Kita ingin masyarakat mempunyai rasa memiliki satu sama lain sehingga kemudian diwujudkan dalam kegiatan, seperti misalnya kerja bakti, saling memberikan bantuan kepada warga tidak mampu.
Ini esensi gotong royong yang sesungguhnya," beber Marsinem.

Sebenarnya, rasulan gratis ini bukan menjadi program unggulannya. Ada sejumlah hal yang menarik perhatiannya untuk dibenahi atau ditingkatkan kembali. Diantaranya adalah reformasi birokrasi di lingkungan pemerintah desa untuk meningkatkan pelayanan kepada masyarakat. Di era kepemimpinannya, pelayanan harus berlangsung cepat sehingga masyarakat bisa merasa nyaman dan tidak membuang waktu.

"Saya juga ingin mengembangkan perekonomian masyarakat, Hargomulyo harus sejahtera," tandas Marsinem.

Terpisah, salah seorang tokoh masyarakat Hargomulyo, Mulyono menyebut bahwa ide rasulan gratis ini sangat mungkin diwujudkan. Ia bahkan secara pribadi siang mengeluarkan kocek untuk membiayai event wayangan dengan dalang Ki Seno. Namun hal ini akan ia berikan secara rutin dengan catatan, yaitu pemimpin dalam hal ini kepala desa bisa memberikan perubahan.

Berdasarkan hasil seluruh jawaban dari masyarakat dalam menjawab indicator yang telah diteliti melalui Short Message Service (SMS), Telepon, wawancara langsung, Facebook (Fb), dan WhatsApp (WA) maka diambil seratus (100) jawaban tertinggi sebagai berikut :

1) Harapan tertinggi sebesar $31 \%$ yaitu meningkatkan pendapatan rakyat sebagai idikator 4, karena masyarakat Hargomulyo selalu mendambakan kehidupan yang layak, oleh karena itu harapan terbesar yang diinginkan adalah murah sandang murah papan, dalam falsafah mereka subur kang sarwo tinandur murah kang sarewo tinuku artinya bahwa warga Hargomulyo menaruh harapan agar para petani bisa bercocok tanam dengan subur dan menghasilkan yang memuaskan karena bertani adalah mata pencaharian pokok mereka serta harga kebutuhan pokok terjangkau oleh masyarakat. Tumpuan tersebut adalah bahwa kepala desa terpilih nanti agar dapat mengupayakan diantaranya menyediakan pupuk dengan harga terjangkau sehingga para petani tidak mengalami kerugian saat panen. Menurut masyarakat yang memilih indicator trsebut menjawab bahwa dengan biaya pengelolaan sawah dan ladang maka hasil panen tidak kembali modal Break Event Point (BEP). 
2) Harapan berikutnya sebesar $15 \%$ yaitu bertanggung jawab sebagai indicator 11 pilihan masyarakat berikutnya mempunyai alas an bahwa calon kepala desa harapan mereka dapat mempertanggungjawabkan dalam segala konsekuensinya, maksudnya adalah bahwa segala yang terjadi didalam pemerintahan menjadi tanggung jawab seorang pemimpin, karena pemimpin mempunyai otorisasi tertinggi dalam instansi yang dipimpinnya. Karena seorang kepala desa mengelola keuangan Negara yang tidak sedikit maka dengan harapan masyarakat tersebut dapat dipergunakan sesuai perundang-undangan dan peraturan yang berlaku.

3) Komunikatif sebagai indicator 2 memperoleh jawaban sebesar $13 \%$, harapan masyarakat berikutnya adalah bahwa sebagai calon pemimpin diharapkan dapat berkomunikasi dengan siapapun, dimanapun, dan kapanpun hal tersebut karena bahwa komunikasi yang baik akan menghasilkan kepemimpinan yang baik pula. Komunikasi dapat berupa komyunukasi yang bersifat horizontal dan dapat pula bersifat vertical, horizontal adalah komunikasi antara atasan dengan bawahan dan komunikasi vertical adalah komunikasi antara pejabat yang sederajat. Komunikasi dari bawahan ke atasan adalah merupakan usulan, tuntutan, pengajuan dan bahkan harapan-harapan lain yang ditunggu dari pemimpin untuk masyarakat wilayah yang dipimpinnya.

4) Merakyat sebagai indicator 3 memperoleh jawaban $11 \%$, artinya bahwa pemimpin harapan rakyat Hargomulyo bisa membaur dengan masyarakat. Pemimpin yang merakyat atau dekat dengan rakyat akan mudah menjalankan roda pemerintahan, karena seorang kepala desa yang dekat dengan rakyat maka akan mendapat dukungan penuh dari warga masyarakat, sehingga segala program kerja pemimpin akan dapat dilaksanakan dengan baik dan mecapai tujuan sesuai yang telah ditetapkan sebelumnya.

5) Jujur sebagai indicator 10 memperoleh jawaban sebesar $11 \%$, kejujuran adalah suatu syarat mutlak dalam memimpin suatu wilayah, dengan sifat jujur maka segala daya upaya memegang tampuk pemerintahan akan berjalan dengan baik, dengan kejujuran pula maka penggunaan dana pemerintah akan dapat dilaksanakan dengan baik. Sifat jujur pula yang akan menuntun seorang pemimpin berjalan dengan bijaksana dan segala program kerja akan dapat terlaksana sesuai anggaran. Dengan pemimpin yang jujur maka tindakan penyelewengan keuangan Negara akan dapat diminimalisasi.

6) Aktif dalam kegiatan RT/RW. sebagai indicator 1 memperoleh jawaban 8\%, dengan keaktifan mengikuti kegiatan dalam lingkungan masyarakat baik tingkat Rukun Tetangga (RT) dan Rukun Warga (RW) maka aspirasi masyarakat cepat tersampaikan. Dengan terjun ke masyarakat bawah dan cepatnya aspirasi ditangani maka harapan masyarakat terhadap pemimpin dapat segera dilaksakanan sehingga kehidupan masyarakat akan terasa lebih baik dan lebih sejahtera.

7) Bersih sebagai indicator 8 memperoleh jawaban $5 \%$, harapan mempunyai pemimpin yang bersih adalah menjadi keinginan seluruh masyarakat. Bersih dari masa lalu, saat ini dan masa yang akan datang. Sehingga seorang yang notabene bersih dapat menjalankan tampuk kepemimpinan secara amanah atau bisa memegang teguh kepercayaan dari rakyat yang memilihnya. Apabila seorang pemimpin yang mempunyai predikat bersih maka wilayah yang dipimpinnya akan menjadi adil dan makur. Dalam pepatah jawa gemah ripah loh jinawi kerto toto lan raharjo artinya rakyat makmur dan hidup tenteram.

8) Terkenal sebagai indicator 6 memperoleh jawaban 3\%, indicator terkenal menjadi pilihan ke depalan dari sereatus pemilih sebagai contoh, dalam hal ini rakyat justru dapat menentukan dan memilih bahwa calon tersebut layak atau tidak untuk dipilih sebagai pemimpin. Kadangkadang kandidat terkenal di mata masyarakat dari segi negatifnya, sehingga dengan sendirinya atau hokum alam bahwa kandidat tersebut tidak akan mendapat kepercayaan dari kalangan pemilihnya, berbeda halnya bahwa kandidat tersebut terkenal karena kebaikannya atau positif dengan sendirinya akan mengisi hati pemilihnya dan otomatis kandidat yang terkenal seperti akan mempunyai peluang besar keluar sebagai pemenang karena di harapkan oleh pemilihnya.

9) Agamis sebagai indicator 7 memperoleh jawaban 3\%, di wilayah Hargomulyo ternyata predikat agamis bukan menjadi daya tarik secara mutlak. Dilihat dari kegiatan sehari-hari bahwa secara umum di wilayah Hargomulyo kurang mementingkan dalam hal ibadah, terbukti dari 
jawaban setaus oeang pemilih hanya terdapat 3\% saja. Dilihat kesehariannya di wilayah Hargomulyo, salah satu pedukuhan yang mempunyai hak pilih laki-laki sebayak 336 jiwa belum terhitung anak usia dibawah 17 tahun terjadi ketimpangan melaksanakan beribadah pada hari jumat. Pada saat ibadah pada hari Jumat penduduk 336 plus anak-anak yang mungkin jumlahnya melebihi penduduk dewasa terbukti sholat jumat berjamaah hanya sekitar 30-an jamaah. Bagi mereka yang memilih agamis maka mereka menjelaskan dan berharap bahwa calon yang bersifat agamis akan dapat menjalankan roda pemerintahan dngan penuh rasa tanggung jawab.

\section{KESIMPULAN}

Kesimpulan tentang Motivasi masyarakat dalam memilih pemimpin pada pemilihan kepala desa Hargomulyo bertumpu pada peningkatan pendapat rakyat. Artinya bahwa pemimpin yang baru diharapkan dapat membuat rakyat sejahtera secara umum, tercermin pada 100 orang sebagai contoh survey tertinggi bahwa $31 \%$ merupakan pilihan yang mutlak. Harapan berikutnya sebesar $15 \%$ yaitu bertanggung jawab. Komunikatif sebagai indicator ke 2 memperoleh jawaban sebesar 13\%, Merakyat sebagai indicator ke 3 memperoleh jawaban $11 \%$, Jujur sebagai indicator 10 memperoleh jawaban sebesar $11 \%$, Aktif dalam kegiatan RT/RW. sebagai indicator 1 memperoleh jawaban $8 \%$, Bersih sebagai indicator ke 8 memperoleh jawaban 5\%, Terkenal sebagai indicator 6 memperoleh jawaban 3\%, dan Agamis sebagai indicator ke 7 memperoleh jawaban $3 \%$.

\section{SARAN}

Mengingat warga Desa Hargomulyo berharap kepada calon pemimpin bahwa siapapun yang jadi dapat menikatkan taraf hidup rakyat dalam arti meningkatkan pendapatan oleh karena itu pemipin yang terpilih penulis sarankan ahar dapat memenuhi harapan masyarakat. Slah satu yang terprnting di wilayah tersebut adalah mengatasi kekurangan air. Seorang pemimpin perlu mencari jalan solusi supaya yang selama ini terjadi kekurangan air dapat diatasi atau dicari solusinya.

Saran dari penulis adalah untuk warga masyarakat agar yang namanya sifat agamis menjadi prioritas, jangan sampai beranggapan sholat tidak sholat sama saja. Hal seperti itu sering penulis dengar dari jawaban masyarakat, bahkan di ajak ibadah sangat sulit. Kalau masyarakat berharap dapat meningkat pendapatan dan taraf hidup yang lebih layak apalagi makmur ya harus dan wajib mengingat Allah swt. Dengan cara rajin ibadah. Karena Allah tempat menyembah dan tempat meminta. Kalau pemimpin itu tempat meminta tetapi minta menjadi sarana bukan pemberi, karena pemimpin yang baik adalah yang agamis.

\section{DAFTAR PUSTAKA}

SUMBER BUKU:

Cut Zurnali, 2004, Pengaruh Pelatihan dan Motivasi Terhadap Perilaku Produktif Karyawan Divisi Long Distance PT Telkom Tbk, Tesis, Unpad, Bandung

Robbins, Stephen P.; Judge, Timothy A. (2008). Perilaku Organisasi Buku 1, Jakarta: Salemba Empat. Hal.222-232

Siagian, (2003), Manajemen Sumber Daya Manusia, Bumi Aksara, Jakarta.

Sugiyono, (2005), Metode Penelitian Administrasi, Alfabeta, Bandung. , (2017), Statistik untuk Penelitian, Alfabeta, Bandung.

Suharsimi Arikunto, (2006), Prosedur Penelitian, Rineka Cipta, Jakarta.

SUMBER JURNAL:

Enjang Sudarman, (2017), Kajian tentang Prilaku Kepemimpinan Kepala Sekolah dan Budaya Sekolah terhadap Kinerja Guru di Sekolah Dasar Negeri Kecamatan Cibuaya Kabupaten Karawang, Equilibrium Point, Jurnal Manajemen dan Bisnis, Volume 1, Nomor 1, Nopember 2017, ISSN 2598-4837, STIMA IMMI, Jakarta.

Muhammad Anno Zuhrias, (2017), Hubungan Kepemimpinan terhadap Motivasi dan Kinerja Pegawai pada CV. Graha Agri Indonesia Bogor, Equilibrium Point, Jurnal Manajemen dan Bisnis, Volume 1, Nomor 1, Nopember 2017, ISSN 2598-4837, STIMA IMMI, Jakarta.

Muhammad Asari dan Suminarsih, (2015), Pengaruh Disiplin, Motivasi dan Kemampuan Kerja terhadap Kinerja Karyawan di PT Century textile Industry Tbk, Jurnal Pengembangan Wiraswasta, Volume 17, Nomor 02, Agustus 2015, ISSN 1411-710X, STIE IPWIJA, Jakarta.

R. Sulistiawan, (2017), Pengaruh Motivasi terhadap Kinerja, Equilibrium Point, Jurnal Manajemen dan Bisnis, Volume 1, Nomor 1, Nopember 2017, ISSN 2598-4837, STIMA IMMI, Jakarta. 
Widodo, (2015), Hubungan Kepemimpinan dan Motivasi dengan Kinerja, Jurnal Pengembangan Wiraswasta, Volume 17, Nomor 02, Agustus 2015, ISSN 1411-710X, STIE IPWIJA, Jakarta.

Widodo, (2017), Hubungan Kepemimpinan Kepala Sekolah dan Motivasi terhadap Kinerja Guru SMK Arrahman Depok, Jurnal Pengembangan Wiraswasta, Volume 19, Nomor 01, April 2017, ISSN 1411-710X, STIE IPWIJA, Jakarta.

Widodo, (2018), Hubungan Motivasi Kepala Sekolah terhadap Kinerja Guru pada SMK YAJ Depok Jawa Barat, Prosiding Manajerial \& Kewirausahaan Call for Paperrs $3^{\text {rd }} \&$ Seminar Nasional, penelitian Manajemen dan Kewirausahaan di Era Digital, Volume 3, Nomor 01, Agustuts 2018, IPWIJA Jakarta

Widodo dan Indri Astuti, (2017), Motivasi Kepala Desa dalam Pembangunan Ekonomi (Studi Kasus pada Wilayah Desa Hargomulyo, Gedangsari, Gunung Kidul), Equilibrium Point, Jurnal Manajemen dan Bisnis, Volume 2, Nomor 2, Agustus 2018, ISSN 2598-4837, STIMA IMMI, Jakarta.
Widodo, (2019), Pengaruh Persepsi Karier dan Kedisiplinan terhadap Prestasi Kerja, Jurnal Pengembangan Wiraswasta, Volume 21, Nomor 01, April 2019, ISSN 1411-710X, STIE IPWIJA, Jakarta

\section{SUMBER INTERNET :}

https://www.hargomulyo-gedangsari.desa.id/first https://jogja.polri.go.id/polres_gunungkidul/ polsek_gedangsari/website/? $\mathrm{p}=7550$

http://belajarpsikologi.com/pengertiankepemimpinan-menurut-para-ahli/, diakses pada tanggal 20 Februari 2014.

http://kepemimpinan-fisipuh.blogspot.com/2009/ 03/definisi-kepemimpinan.html, diakses pada tanggal 20 Februari 2014. 